\title{
The Contribution of International Trade and Investment to Economic Growth in Thailand
}

\author{
Apinya Wanaset \\ Associate Professor, School of Economics, Sukhothai Thammathirat Open University, Thailand
}

\begin{abstract}
The objective of this study has two-fold: 1) to overview of international trade and investment of Thailand during the pass two decade in order to investigate trend and structural change of international trade and international investment; 2) to study the relationship among international trade, foreign direct investment, foreign portfolio investment and economic growth. The study employed descriptive and quantitative analysis techniques together with in-depth interview. The descriptive analysis explained general conditions of international trade and investment with some problems in Thailand. Econometrics including co-integration and causality test was employed for the quantitative analysis. The variables used in this study were time series data including Gross Domestic Product (GDP), international trade (X+M), foreign direct investment (FDI) and foreign portfolio investment (FPI) from the period of 1998-Q1 through 2016-Q4.

The results of this study showed that 1) In the first period before the US economic crisis in 2007, Thai exports expanded by an average of $11.70 \%$ per year, partly due to the baht's weakening during the adjustment period to the managed float exchange rate system in 1997. It declined in the latter period (2008 - 2016) about $4.49 \%$ per year. Since the productivity was unable to increase in line with the higher wages in 2011. However, in the last decade, they gained the lower expansion in international trade and investment than they were before. This was partly due to the decrease in Thai competitiveness and the relocation of production base from Thailand. Excluding foreign portfolio investment, it still has good enlargement with the favorable regional stock markets. 2) All variables have a long run relationship. In the first period (1998-2007), economic growth has positive impact on international trade and investment. At the same time, international trade and foreign portfolio investment promote economic growth as well. Only foreign direct investment has no impact on economic growth. For the second period (2008-2016), these variables were less correlated due to the increasing degree of openness. Therefore, many economic factors were affected by the external factors. Only international trade has positive impact on both economic expansion and foreign portfolio investment.
\end{abstract}

Keywords: International Trade, International investment, Economic growth 